Journal of Environmental Science and Public Health

doi: $10.26502 / \mathrm{jesph} .96120050$

fortune

Volume 3, Issue 1

Review Article

\title{
Introduction of Biodiesel as a Sustainable Resource
}

Sylvia Adipah*

Department of Environmental Engineering and Science, Chongqing University, Chongqing, China

"Corresponding Author: Sylvia Adipah, Department of Environmental Engineering and Science, Chongqing University, Chongqing 400044, China, E-mail: fransi1351@yahoo.com

Received: 06 December 2018; Accepted: 31 December 2018; Published: 08 February 2019

\begin{abstract}
Increasing population, economy and rapid urbanization have accelerated in the use of bioenergy. The conditions and factors surrounding the expectation and realities of non-edible oils for biodiesel are necessitating efforts to diversify feedstock. Modern technology for bioenergy can be used as biofuel for transport as well as biomass for heat and electricity production. Currently, biodiesel can be produced from edible plant oils such as soybean, rapeseed, palm and sunflower. In this study, we aim at the importance of using biodiesel as a renewable energy.
\end{abstract}

Keywords: Bioenergy; Renewable resource; Biofuel; Vegetable oil; Fuel injection

\section{Introduction}

\subsection{Overview of bio energy}

Bioenergy is one of the renewable energies. It's contained in living or biological organisms. Bioenergy can be gotten from organic matter, industrial, commercial or agricultural products. During plants growth, carbon dioxide is released and its energy is classified as carbon-neutral known as bioenergy. Bio-energy covers two aspects thus biofuel and biomass, Biofuel is the process where plants material is being transformed into liquid fuel while biomass is burning of plants material to create energy for use. This energy is used for transportation, heat and production of electricity.

\subsection{Biomass energy}

Biomass is an organic matter processed form of plants and animal manure including trees, algae and crops. Biomass can also be obtained from plants and animal material, industrial, human and animal wastes. Plants absorb energy 
from the sun and use it to produce their food through photosynthesis; this energy therefore can be used as fuel that is obtained from burning biomass. Biomass releases heat and carbon dioxide during the burning process that is absorbed while the plant is growing. This energy can act as a form of renewable energy used directly thus for heating or cooking and indirectly by converting into liquid or gaseous fuel. At a constant rate, burning of biomass produces heat water and steam to improve the environment as a clean or renewable energy. The advantages of biomass energy include less air emissions; reduction of landfills and reliance on foreign oil. As non-renewable, fossil-based fuel resources are depleting, research and development on alternative renewable energy is growing.

Biodiesel has advantage over petroleum diesel when compared. For example, biodiesel produces lower exhaust emissions, biodegradable, non-toxic, renewable and essentially free of sulfur making biodiesel a renewable energy and environmental friendly towards sustainable resource. In most countries within the sub-region, there are several forest plant species, which have seeds from which oil could be produced [1]. Vegetable oils are obtained from seeds and fruits of plants, which can be found in different parts of the world. Different kinds of plants have oil-producing seeds and this seeds include Groundnuts, sunflower, palm nuts and soybeans [2]. Allanblackia florinbunda is a woody dicotyledonous that belongs to the family Guttiferae and genus Allanblackia. It is a green plant that grows well in rainforest regions as well as on cocoa farms therefore can be found in Africa (Ghana, Cameroon, Gabon, Congo Brazzaville and Uganda). This oil found can be used for cooking, manufacturing of spreads, making soap, beauty products and preparation of medicine. Allanblackia florinbunda seed oil has high melting point and better food value than others [3]. The seeds of A. floribunda contain $6.0 \%$ water, $2.2 \%$ ash, $3.6 \%$ crude protein, $3.1 \%$ crude fibre, $20.7 \%$ carbohydrate and $64.4 \%$ oil.

\section{Biofuels}

Biofuels are energy that store the energy obtained from plants, animals and microorganisms and organic wastes. Biofuels are renewable energy sources indicating that fresh plants can be regrown. Advantages and disadvantages of biofuels depend on type of biofuel, feedstock and the technology used. Biodiesel may be used to replace petroleum diesel, which is economical and efficient.

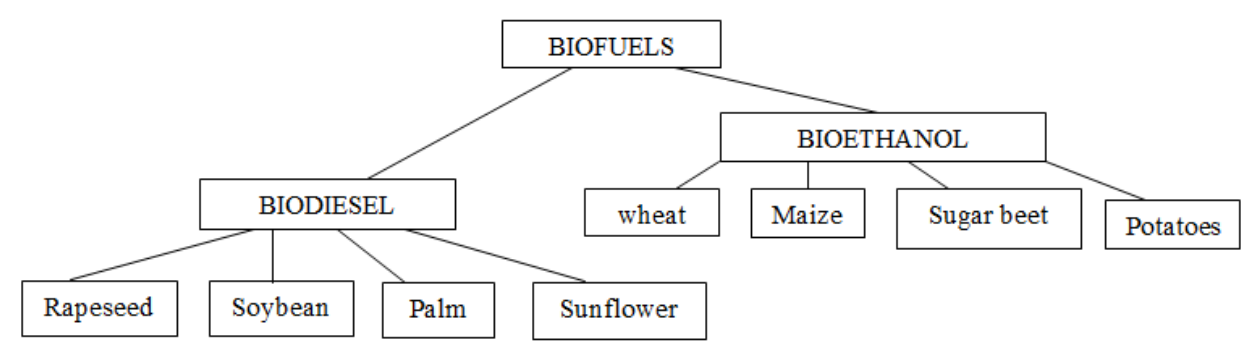

Figure 1: Sources of main liquid biofuels for automobiles [4]. 


\section{Biodiesel}

Biodiesel is an oxygenated, non- toxic, sulfur-free, biodegradable, and eco-friendly. It is a renewable resource and may be used as animal fats, vegetable fats, used for cooking and transportation fuel because its fuel have mono-alkyl esters of long chain fatty acids meeting a standard requirements (ASTM OR European standards). One main process for producing biodiesel is transesterification. Biodiesel have high viscosities and this can be derived from the injection and atomization characteristics of vegetable oil, viscosity of vegetable oil can be reduced to improve the efficiency of diesel engines and this can be obtained by converting vegetable oil into biodiesel. The four main methods to solve problem occurrence of high fuel viscosity are dilution, micro emulsification, pyrolysis, and transesterification.

\subsection{History of biodiesel}

Dr. Rudolf Diesel invented and experimented on diesel engine using 100\% peanut oil which he had failures at World Exhibition in Paris in 1900. In 1911, he realized vegetable be a successful story to improve diesel engine effectively. In 1912, Diesel indicated, "The use of vegetable oils for diesel engine may be of no importance today." Due to Dr. Diesel's untimely death in 1913, a foundation for a society was created regarding fuel with clean, renewable and locally grown fuel was studied [5-10].

\subsection{Advantages of biodiesel}

3.2.1 It's renewable: Biodiesel as a renewable resource such as organic oils, fats, and tallows that can be regrown, reproduced, reused and as such allowing more crops to be grown if needed. Biodiesel can be used as a fuel instead of using petroleum diesel.

3.2.2 It's economical: Relatively biodiesel is less expensive and can be produced on a small scale compared to petroleum diesel. Because of its economical low price, most people can save money on their fuel bill.

3.2.3 It supports farmers: Biodiesel helps the farming society that grows the feedstock with money flowing since these feedstocks are used for biodiesel production. Biodiesel is a renewable energy and farmers can grow more seed crops for its production.

3.2.4 It's environmentally friendly: Studies by the US National Renewable Energy Laboratory indicate drops in several key areas that help the environment. Carbon dioxide is reduced and this does not bring any health related problems in the future.

3.2.5 It's production is simple: Biodiesel is an innovative technology and studies have made it easily and simple to do. It is been found to be an incredibly fulfilling experience. 
3.2.6 It reduces dependency on crude oil: Biodiesel replaces petrodiesel reducing the amount of crude oil used up therefore reducing the dependency on the limited resources. This is a great step toward reducing dependence on a fuel that may not be around forever.

3.2.7 It's good for the engine: Unlike petrodiesel, biodiesel has a much higher lubricity to itself. Using biodiesel creates less tear and wear when used on regular basis. Since biodiesel is less polluting, it implies that it's easier on the engine.

3.2.8 It's the perfect alternative fuel: Most of these vehicles using natural gas, propane or ethanol must undergo necessary conversion to use alternative fuel and there's no going back once the fuel is changed unlike biodiesel.

3.2.9 Environmental benefits of biodiesel: Petroleum diesel are expensive and have harmful environmental effects, the availability of petrodiesel is limited and using biodiesel creates an alternative energy resource. Biodiesel, fuel that is chemically prepared from vegetable oil, provides an environmentally friendly substitute for diesel fuel. Its biological origin makes it biodegradable and non-toxic. Other advantages of biodiesel fuel over petroleum diesel are the increased oxygen content, no sulfur content, increased lubricity, and lower emissions of particulate matter upon combustion.
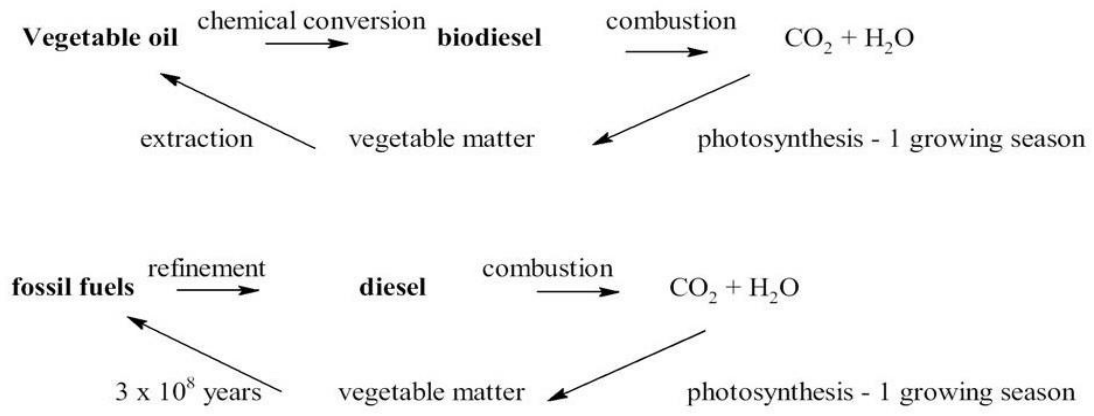

Figure 2: A simple cycle of carbon dioxide of biodiesel and fossil fuel with different time frames.

\subsection{Challenges of using biodiesel}

Biodiesel has higher nitrogen oxide NOx emissions than petrodiesel. Atmospheric nitrogen is been oxidized due to its high cetane rating and oxygen contents. Water present in storage tank processes reduces the heat of combustion of the fuel, leading to more smoke, harder starting, and less power. It freezes to form solid ice near $0^{\circ} \mathrm{C}\left(32^{\circ} \mathrm{F}\right)$, which are sites for gel formation of the fuel, decreasing its flow properties. The growth of microbes can plug up a fuel system, which is increased by water presence. This is a challenge for most biodiesel users with heater fuel tanks. 


\section{Conclusion}

The increase in energy demand and cost, environmental considerations, reduction in fossil fuel reserves and threats on food security is drawing attention of researchers for viable alternative energy from renewable resources to augment energy and yet maintain food security.

\section{References}

1. West AH, Posarac D, Ellis N. Simulation, case studies and optimization of a biodiesel process with a solid acid catalyst. International Journal of Chemical Reactor Engineering 5 (2007): 3.

2. Ihekoronye AI, Ngoddy PO. Integrated Food Science and Technology for the Tropics, Tropical Fruits and Vegetables. Macmillan Education Ltd. London and Oxford (1985): 306.

3. Energy Information Administration. Electricity flow. Annual Energy Review (2007).

4. Demirbas Ayhan. Biodiesel-a realistic fuel alternative for diesel engines. Springer (2008).

5. Li M, Zheng Y, Chen Y, et al. Biodiesel production from waste cooking oil using a heterogeneous catalyst from pyrolyzed rice husk. Bioresource Technology 154 (2014): 345-348.

6. Ofori D, Kehlenbeck K, Munjuga M, et al. Allanblackia species: A model for domestication of high potential tree crops in Africa. II International Symposium on Underutilized Plant Species: Crops for the Future-Beyond Food Security (2013).

7. Patle DS, Sharma S, Ahmad Z, et al. Multi-objective optimization of two alkali catalysed processes for biodiesel from waste cooking oil. Energy Conversion and Management 85 (2014): 361-372.

8. Phan AN, Phan TM. Biodiesel production from waste cooking oils. Fuel 87 (2008): 3490-3496.

9. United States Department of Agriculture (USDA). Oilseeds: World markets and trade (2018).

10. West AH, Posarac D, Ellis N. Assessment of four biodiesel production processes using HYSYS. Plant Bioresource Technology 99 (2008): 6587-6601.

Citation: Sylvia Adipah. Introduction of Biodiesel as a Sustainable Resource. Journal of Environmental Science and Public Health 3 (2018): 99-103.

This article is an open access article distributed under the terms and conditions of the Creative Commons Attribution (CC-BY) license 4.0 